\title{
Summary of Findings and Recommendations
}

\section{U.S. INTERESTS: WHAT'S AT STAKE FOR THE UNITED STATES IN SOUTH AFRICA?}

- Protecting U.S. military and strategic interests and minimizing Soviet influence in southern Africa. Unimpeded use of the Cape sea route, along which much of the West's oil passes, is of great strategic importance to the United States. So is curbing Communist influence in the region. The question is how best to go about protecting these interests.

- Ensuring adequate supplies of key minerals imported from South Africa. Four groups of minerals exported by South Africa are strategically and economically important to the United States: chromium and ferrochrome, manganese and ferromanganese, platinum, and vanadium.

- Advancing political freedom and civil liberties for all South Africans. This concern grows out of our national history and fundamental American moral and philosophical beliefs. The denial of basic freedoms under apartheid also risks sustained racial violence in South Africa that would trigger bitter controversy within the United States, controversy that could erode the consensus favoring progress on race relations in this country. The United States therefore has a strong interest in promoting movement, with a minimum of violence, toward a system in which political power is shared in a manner acceptable to all racial groups and the civil liberties of all South Africans are protected.

- Maintaining satisfactory diplomatic and commercial relations with other African countries. The United States has $\$ 4.5$ billion in direct invest- 
ment in African countries other than South Africa and \$13.7 billion worth of annual trade. Nigeria is particularly significant as the United States' second largest foreign oil supplier and a leading African opponent of apartheid. Diplomatic and political support of the African countries is important to the United States, especially in international organizations, and is linked to a considerable extent to U.S. policies toward South Africa.

- Maintaining commercial relations with South Africa. The United States has $\$ 2$ billion of direct investment in South Africa and trade totaling $\$ 3.4$ billion a year.

\section{SOUTH AFRICAN REALITIES AND TRENDS AND THE COMMISSION'S FINDINGS}

- Whatever the South African government does to reinforce the status quo, black forces inside the country will eventually alter it.

- The final battle lines have not yet been drawn in South Africa. Fundamental political change without sustained, large-scale violence is still possible, although time is running out.

- For blacks and whites, certain positions are nonnegotiable. For blacks, an acceptable solution must give them a genuine share in political power. For whites, an acceptable solution cannot be based on a winner-take-all form of majority rule. This is both the core of the problem and, because the nonnegotiables are not necessarily irreconcilable, the key to its solution.

- Many white leaders appear to accept the need to undertake some real reforms, and many black leaders appear to accept that fundamental changes will not come quickly and that compromises will have to be made. Younger blacks, however, are growing more radical and impatient.

- There is much ferment and many contradictory forces at work in South African society. Continuing government repression coincides with some positive reforms and a great deal of debate among all racial groups. There is no clear pattern for the future.

- Whites are not ready to accept blacks as equals or to share power with them. Some whites talk of the need to do so but have not begun to address the issue in a way satisfactory to blacks. And blacks do not yet possess sufficient leverage to compel whites to share power.

- Black and white South Africans must make their own choices, and whatever system they freely and fairly choose should be respected by the United States and the international community.

- There are no easy solutions for South Africa. The choice is not between "slow peaceful change" and "quick violent change" but between a slow, uneven, sporadically violent evolutionary process and a slow but much more violent descent into civil war. 
- Both paths could lead to genuine power sharing. The United States should do what it can to encourage the former course because it promises less bloodshed and economic destruction and a government more responsive to the rights of all groups, and is more likely to protect the full range of U.S. interests.

- The active collaboration of the South African government, whatever its ideology, is not an important factor in protecting the Cape sea route. A greater source of danger to the West is the growth of Soviet influence in the region, promoted by white intransigence in South Africa, growing political instability, rising levels of racial violence, and armed conflict.

- Stoppages in the supply of key minerals exported from South Africa, should they occur, are likely to be partial, intermittent, and short term in duration. Medium-term (five-to-ten-year) and long-term (more than ten-year) interruptions are unlikely.

\section{POLICY RECOMMENDATIONS: OBJECTIVES AND ACTIONS}

We recommend a policy based on the simultaneous pursuit of five objectives. These are intended to serve as an integrated framework for action by both the U.S. government and U.S. private organizations. Actions supporting the objectives are intended to be put into effect as soon as possible, except for those associated with Objective 2 . They should remain in effect until a genuine sharing of political power, acceptable to all races, is implemented in South Africa.

\section{Objective 1}

To make clear the fundamental and continuing opposition of the U.S. government and people to the system of apartheid, with particular emphasis on the exclusion of blacks from an effective share in political power.

Actions taken to pursue this objective show black and white South Africans and all those concerned with the issue that the United States' opposition to apartheid is profound and constant. If this point is made clearly and continuously, misunderstanding of U.S. motives in recognizing and encouraging partial progress in South Africa (see Objective 2) and remaining engaged with that country in other ways (see Objective 3 ) should be minimized.

The actions for this objective fall into two categories. First, those to be implemented by the U.S. government, which include broadening the arms embargo to cover foreign subsidiaries of U.S. companies, broadening the nuclear embargo, and withholding diplomatic recognition and economic aid from the independent homelands.

The second category applies to U.S. corporations. Those in South Africa 
should not expand their operations, and those not already there should stay out. Those in South Africa should commit a generous proportion of their corporate resources-determined in accordance with a specific "social development expenditure standard"- to improving the lives of black South Africans, and should subscribe to and implement the Sullivan Principles. Compliance with the principles should be effectively monitored. All these measures should be undertaken on a voluntary basis for the moment, and the government should endorse them as important parts of overall U.S. policy.

Disinvestment and other major economic sanctions are not recommended under current circumstances.

\section{Objective 2}

To promote genuine political power sharing in South Africa with a minimum of violence by systematically exerting influence on the South African government.

Effective pressure for change in South Africa requires not only a clearly communicated overall posture toward apartheid, but also continuing government-to-government contact to maximize the weight and credibility of the United States' views on particular events in South Africa. The United States has limited leverage. It cannot alter the situation in South Africa radically, but it can encourage positive and discourage negative initiatives by the South African government through the use of inducements and pressures.

Many pressures are already in force, but there are others that could be used if the South African government showed signs of adopting more repressive policies. These include diplomatic moves such as reducing the levels of U.S. representation in South Africa and South African representation in the United States. Barring the export of particular categories of U.S. goods, services, and technology through the Export Administration Act is another avenue for possible action. A case in point is the export of American technology in oil exploration and drilling, on which South Africa relies heavily in its efforts to find the only major energy resource it now lacks.

Inducements tend to be the reverse of pressures. If the South African government showed itself to be serious about genuine change through specific actions, the United States should take commensurate steps toward a closer and more friendly relationship.

\section{Objective 3}

To support organizations inside South Africa working for change, assist the development of black leadership, and promote black welfare.

The purpose of this objective is to strengthen the forces for change within South Africa and provide a mandate for constructive action by the U.S. privatesector organizations in the United States. Specific actions are proposed in sup- 
port of black and multiracial labor unions, educational programs, and public interest, self-help, and other organizations in South Africa.

\section{Objective 4}

To assist the economic development of the other states in southern Africa, including reduction of the imbalance in their economic relations with South Africa.

Strengthening the economies of these states and making them less dependent on South Africa serves all U.S. interests. Actions for pursuit of this objective include aid on a regional basis to the newly formed Southern African Development Coordination Conference (SADCC), particularly for the development of agriculture, transport, communications, and energy resources. Increased aid for Zimbabwe is emphasized as well as encouragement to the private sector to expand trade and industrial development in the region.

\section{Objectlve 5}

To reduce the impact of stoppages of imports of key minerals from South Africa.

Actions taken to pursue this objective are not intended to end U.S use of South African minerals, but to minimize the impact of potential stoppages of imports of the four key minerals: chromium and ferrochrome, manganese and ferromanganese, platinum, and vanadium. The recommended actions include increasing stockpiles, particularly of ferrochrome and ferromanganese, developing a national minerals policy and contingency plans, some diversification of sources of supply, and development of the transport systems of the other mineral-supplying states in the region.

\section{GENERAL RECOMMENDATIONS FOR THE U.S. GOVERNMENT}

- Encourage the United States' allies to adopt similar policies.

- Issue a white paper defining U.S. interests in South and Southern Africa and describing the overall framework for policy.

- Establish a high-level interdepartmental committee to coordinate policy toward South Africa. 


\section{U.S. Interests}

Protecting U.S. Military/Strategic Interests and Minimizing Soviet

Ensuring Adequate Supplies of Key Minerals

Advancing Political Freedom and Civil Liberties

Maintaining Satisfactory Diplomatic and Commercial Relations with Other African Countries

Maintaining Commercial Relations with South Africa

Objectlves for U.S. Policy

Policy Actions

(se日 text)
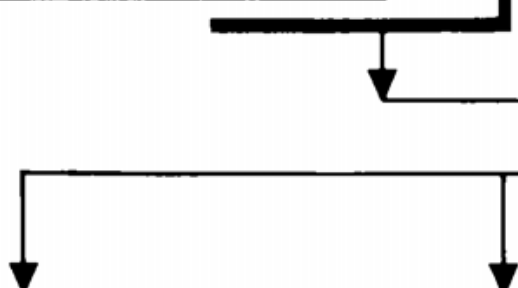

2. Promote genuine political power sharing in South Africa with a minimum of violence by systematically exerting influence on the South Aftican government
1. Demonstrate the fundamental opposition of the U.S. to apartheid
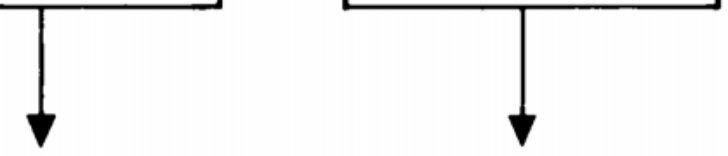


\section{FRAMEWORK}

South African Realities and Trends

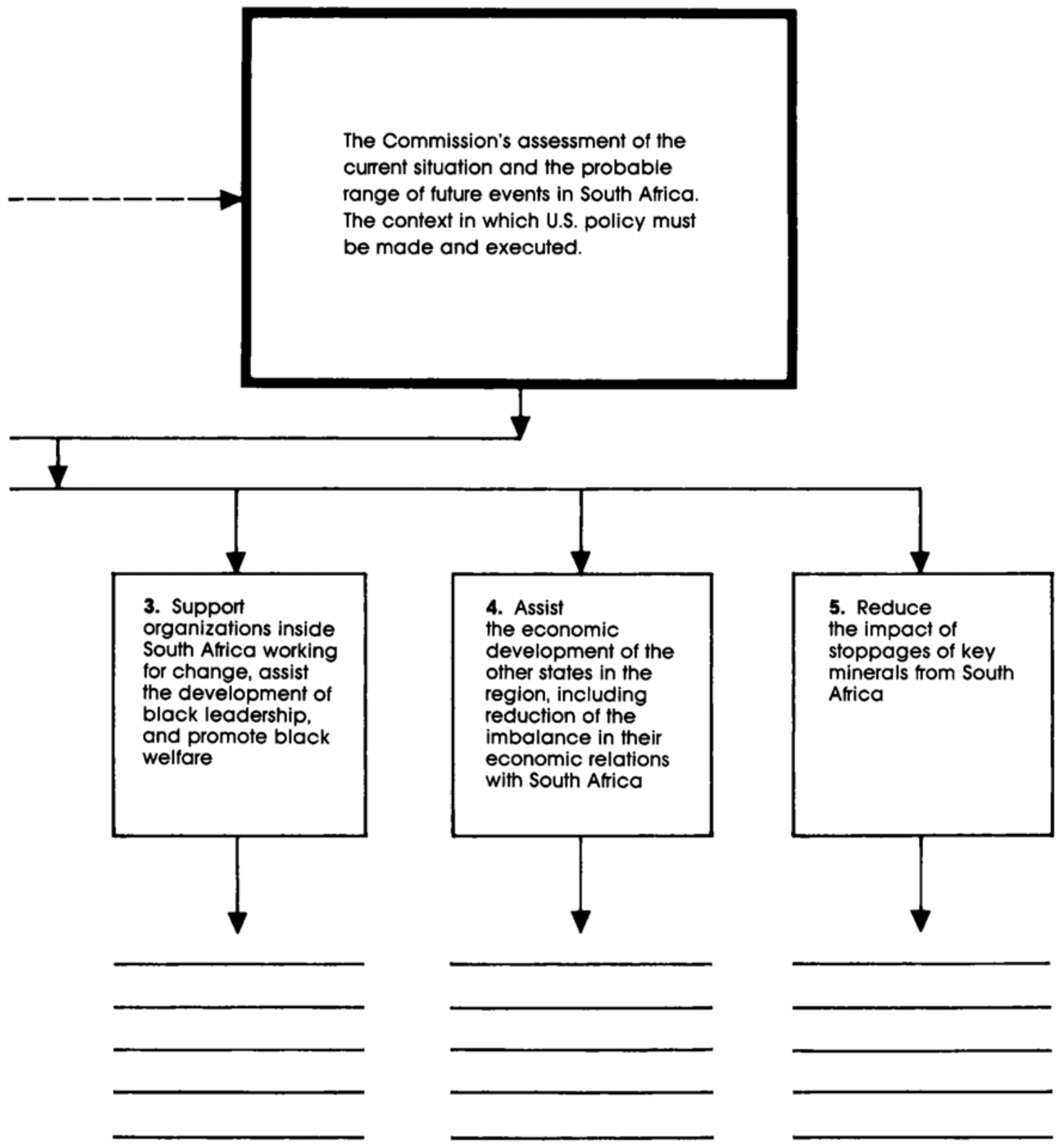


